\title{
Research the Corporate Culture of Students Using Neural Network Models
}

\author{
Sergiy V. Kovalevskyy ${ }^{1}$, Ludmila V. Kosheva ${ }^{2}$ \\ ${ }^{1}$ Donbas State Engineering Academy, Faculty of integrated technology and equipment, Kramatorsk, Ukraine \\ ${ }^{2}$ Donbas State Engineering Academy, Faculty of Economics and Management, Kramatorsk, Ukraine \\ Email address: \\ kovalevskii@i.ua (S. V. Kovalevskyy), kosheva@i.ua (L. V. Kosheva)
}

\section{To cite this article:}

Sergiy V. Kovalevskyy, Ludmila V. Kosheva. Research the Corporate Culture of Students Using Neural Network Models. American Journal of Neural Networks and Applications. Vol. 1, No. 2, 2015, pp. 43-47. doi: 10.11648/j.ajnna.20150102.13

\begin{abstract}
The article contains the new materials reflecting application of neural network models in designing of innovative processes in pedagogic. Such approach, according to authors' point of view, is actual because it is very important to provide quantitative estimations along with quality standards for management of pedagogical processes. They allow to reveal tendencies of innovative pedagogical approaches in education of new generation of young men, but also to correspond to their aspirations, supporting the positive of their socioeconomic influence in every possible way.
\end{abstract}

Keywords: Neural Network, Management, Educational Technology, Production Systems, Innovation, Corporate Culture

\section{Introduction}

Globalization is the main trend of the economy, leading to a new qualitative changes in the field of organizational culture of firms and enterprises. This primarily concerns the evolution of corporate culture. The main features of corporate culture has traditionally consisted of the following main components such as: characters, mission, objectives, principles, code of honor, dresskod, time management, traditions and more. Thus, the corporate culture of the organization is already established intra-system relationships. It gives the owner the opportunity to orient maximum potential employees to achieve the main goal of the subject of the economy - to achieve its maximum economic efficiency.

As globalization today defines the processes that change the image of the world, the actual task is to study the accompanying key factors in systematic form.

\section{Basic Part of Research}

Corporate culture is the spiritual part of the organizational culture. Iía determines the presence and characteristics of internal and external relations of hierarchical organizational culture has the properties of the life cycle, that is subject to the laws of evolution, including the origin, development, maturity, and then replace it with a new image of corporate culture has features to form a cumulative effect, has properties self, which allows to optimize internal resources of the system, providing them with direction most efficient manner.

Corporate culture, established in the organization in the process of changing in form and content. While many often conflicting views on the most integrative culture are the following concepts:

a) The concept of culture, based on the disclosure process of cultural development;

b) concept that focuses on the spiritual work;

c) approach to culture, based on conscious organization and behavior management and livelihoods of people.

Corporate culture as one of the most important components of any organization today is the object of increased attention by managers at various levels. This can be explained by the fact that the inclusion of factors that shape the corporate culture of the organization directly contributes to its effectiveness. In fact, the corporate culture of today should be seen as a basis for corporate governance with a developed system of staff motivation [4].

Available in the program accepted possibility to make algorithm decision logically transparent with final verbalization as symptom-syndrome structures allows to solve this problem somehow. However the received models are still too difficult for perception and aren't logically transparent even after simplification (see Appendix B). Unfortunately, the possibility of studying trained neural network by means of computing experimentation isn't 
provided in NeuroPro. It is possible to try two variants. The first variant is to make the formulas taken from the verbal description of neural network in spreadsheets Excel. Substituting manually one or another value of input parameters, it is possible to watch how these manipulations are reflected in output value. So, eventually, it is possible to track what values factors changes influence result of neural network classification. The essential lack of such variant consists in absence of automation and a search dependences system. But even this way allows to reveal interesting properties of models. We use a modelling variant of models set presented by verbal descriptions, by means of Simulink package. The basic feature of such use is «closing of inputsoutputs» of the general global model where we are not interested in dynamic properties of the received global model, but mutual establishment of values and all its considered variables. On such basis the received modelling results of system influence possibilities on students ability to corporate culture by physical training means.

Considering the corporate culture (CC) must be considered that the concept of $\mathrm{CC}$ is rather arbitrary and organizations under different conditions is shown in different ways. This property reflects the diversity of the Criminal Code of the systemic nature. Considering the system for various positions, we have a real opportunity to "see" different types of CC. This spacecraft is a system of relations and relations between people in the organization.

Corporate culture is defined as a unique set of norms, values, beliefs, patterns of behavior that determine how union groups and individuals in the organization to achieve its goals [1].

In the era of globalization in the language of modern business community, along with other neologisms also included the term "corporate culture", which marked the awareness of the importance of business (and not just for him) is economic, namely, the "human" factor.Traditionally, specialists distinguish three levels of corporate culture. Firstly, superficial or symbolic level, which involves the use of corporate symbols, logo, design and implementation of the flag, the anthem of the company, promotional materials, and the creation of special architectural buildings, architectural design, in which the organization operates, all kinds of stories, myths and legends about the most important events and people of the enterprise. Second, the subsurface level, which combines the values and norms enshrined in the documents and determine the daily activities of the organization. Third, base, or deep, level, providing basic assumption in most cases unconscious, resulting in members based on personal patterns, or backed by successive successful experience of joint actions that characterize the corporate culture. At each of the selected level is the adaptation of employees: on the surface level using employee motivation by creating a positive image of the company, which aims to create and maintain a unique image, strengthen its position among the companies of the segment, the company is created subsurface level team members as a result of the formation of documented imposed norms and values that are in the organization, at a deep level there is awareness of staff targets and values through often hidden, but those that do not require proof of the basic assumptions that are building behaviors within the organization.

Corporate culture - not only the company's image, but also an effective tool for strategic business development. Its formation is always associated with innovation aimed at achieving business goals and, therefore, increase competitiveness [12]. In the "classical" sense of corporate culture is seen as a tool for strategic development by stimulating innovation and change management.

Corporate culture is focused on the internal environment and is manifested primarily and mainly in the organizational behavior of employees. This should include sustainability, efficiency and reliability of national institutional linkages, discipline and culture of their performance, dynamism and adaptability to innovations in the organization, generally (at all levels) management style based on cooperation, active processes and positive self more, manifested in the corporate behavior of employees in accordance with the recognized standards and values that unite the interests of individuals, groups and the organization as a whole [6].

Corporate culture exists in an organization, regardless of whether it creates someone special. But that corporate culture was positive, worked to create a competitive image of the organization, attracted prospective customers and qualified personnel, was the reasoning mechanism for all employees form needs to be purposefully and systematically [6].

Corporate culture allows employees to combine into a single command, which is several times increases productivity, effectiveness and efficiency, to create an effective system of moral incentives.

Meeting basic human needs in the field of professional activity (excellence in the profession, the impact on other people, recognition of peers, the opportunity to fulfill themselves) promotes the desire to work actively, and not just for the paycheck. The very corporate culture workforce is a complex and multifaceted social and psychological phenomenon, subject to change due to the influence of numerous factors vzayemovplyvovyh. It may be subject to positive and negative external factors like natural and motivated, which in turn positively or negatively affects the mentality of professional team members [5].

Today corporate culture is defined by the presence of flexible, moving relationships in its organizational structure, favorable moral and psychological climate in the team, close contacts of workers in the process of innovation and constructive relationships with external organizations corporation.

The philosophy of the company - is the foundation of his existence that determines the relationship between management and employees, between suppliers and consumers, as well as the image of the company. In fact, the 
philosophy of the enterprise defines a set of values transmitted are its employees.

In recent years, corporate culture began to recognize the main index, necessary not only for the proper understanding and managing organizational behavior, but also to motivate employees.

Corporate culture examines common approaches, principles, laws and regularities in the following areas: personality organization, group behavior in the organization, conduct manager in the organization, the adaptation of the internal and external environment, improving organizational effectiveness in the organization.Organizational culture is the culture of the organization, allowing the organization to interact with the environment and carry out its basic functions. A corporate culture reflects the spiritual values as the content of the staff of the organization and its individual members in collaboration with other team members. It certainly follows the main task of team building organization, with its own corporate culture would meet the mission of the company and formed to the image of the company and its functions. In this interpretation rather be together with the concept of "organizational culture of the firm" have the idea of "corporate culture of our employees."Hence an important conclusion: corporate culture our employees must comply with the organizational culture of the firm, but not synonymous with it. Moreover, the corporate culture of our employees to be the medium in which would be implemented in the organizational culture of the firm, ultimately - a decisive success of the company to market products of its activity.

Type of $\mathrm{CC}$ depends on what base and molded value system in the organization. For any group can be divided into 15 to 25 core values, which can be described of staff. Differences in $\mathrm{CC}$, so combinations of values will be determined by staff as a whole and each member organization in particular. Commitment to one particular group of values (monosystemnist) is undoubtedly important and preferable in terms of efficiency [4].

Depending on the nature of the impact of corporate culture on the overall performance of the company distinguish "positive" and "negative" culture [2; 9].

Nowadays it became a tradition to provide three levels of corporate culture [3]:

1. Surface (symbolic) level - that's all a person can see and feel: corporate symbols, logo, designer calendars, company flag, anthem firms, a special architecture of the building, and so on are also symbolic level include myths, legends and history, fl 'associated with the formation of the company, the activities of its leaders and outstanding staff. These legends and stories usually transmitted orally. At this level, things and events easy to find, but not always possible to decipher and interpret in terms of corporate culture.

2. Subsurface level - combining the values and norms deliberately recorded in the documents of the organization and are meant to be guidelines in daily activities of the organization. A typical example of such a guideline value may be "customer is always right" as opposed to the guidelines of the manufacturer's championship in the Soviet period. In particular, the existence of the old values of the primacy manufacturer that is still in process, prevents the efficient work of many organizations and sectors. At this level of study are values and beliefs shared by members of the organization, according to how these values are shown in symbols and language. Perception of values and beliefs is conscious in nature and depends on the willingness of people. Researchers often limited to this level.

3. Basic (deep) level - basic assumptions arising from members on the basis of individual patterns, backed by either changing the successful experience of joint actions and in most cases unconscious, some without the smell and taste "air" corporate culture, which all breathe, but in normal condition not notice. These basic assumptions is difficult to understand even by members of the organization with special focus on this issue. These hidden and taken for granted assumptions steering behavior, helping them to perceive the attributes that characterize the corporate culture.Some researchers propose a detailed structure of corporate culture, highlighting its components are:

1) World Vision - a vision of the world, the essence of man and society to guide the behavior of members and determine the nature of their relationships with other employees, customers, competitors and so on

2) Corporate values, that is, objects and phenomena of organizational life is essential for meaningful spiritual life of workers. Values are the link between culture and spiritual world of the individual, between corporate and individual existence. Personal values are shown in the mind in the form of values, which include as a wide range of social values recognized by person, but not always taken it as their own goals and principles. Therefore, it is possible as incomplete, inadequate reflection of personal values in the minds and consciousness to focus on values that are not real motives.

3) By the behaviors that characterize a particular organization of employees belong to specific rituals and ceremonies, language used in communication, as well as characters that have special meaning for members of the same organization.

4) Standards - a set of formal and informal requirements offered by the organization in respect of its employees. They may be universal and partial, imperative and indicative, and aimed at preserving and developing the structures and functions of the organization. By the standards are so-called rules of the game are a beginner should learn in the process of becoming a member. 
In an organization there may be the following types of subcultures that are pretty hard reject what the organization wants to achieve in general. These may be distinguished: direct opposition to the values of the dominant corporate culture, opposition to the power structure within the dominant culture of the organization, opposition to the designs of relations and interactions supported by the dominant culture.

Corporate culture is a complex, multidimensional phenomenon, an important line of effective policies, including moral norms and values, the current pattern of behavior, and traditions, rituals, and ceremonies aimed at rallying the team, motivate staff to work in the company and achieve high financial performance of the company. Culture is an integral part of focused work with staff focused on creating a team of professionals capable of solving their tasks. Clear and established organizational culture shapes the existence of long-term goals of the enterprise, creates and implements corporate standards that contribute to the achievement of these goals, passes designed values, and targets all members of the organization, including such important categories as young professionals for further implementation and support.

Values that prevail in the individual consciousness employee firm, combine to create the overall atmosphere of values within the organization. This allows to obtain a quantitative description of concepts that dominate the organization. Indeed, values are directly related to corporate culture and are essential elements of the internal structure of personality. Therefore, consideration of values applies more personal level.

It must be emphasized aspect of integration of "values," formed as individual characteristics and display of cultural identity, cultural identity interact with the environment, ie corporate culture. Transformational value - a property of a social object or phenomenon needs, motives and interests of the individual [11].

It is important to put in the operation of the business tasks performed at best performers. This depends on their beliefs and moral qualities, which, in turn, determine their validity, filled with skills, knowledge and desire. Thus, the skills and knowledge to be considered among the beliefs, moral qualities and desires of artists set production targets. This should be encouraged individuality and initiative members of the enterprise or firm.Each company creates a set of rules and regulations to be followed by employees in the workplace. Otherwise, they can not be full members. And in this sense, "full value" should be seen as keeping values that guide the employee on his relationship with the environment. The role of symbolism is that she passed through the values of other members of the organization and form the internal organizational environment.Along with the properties of the Criminal Code has certain features which allows records to build an effective management system. Functions of the Criminal Code, according to many researchers are as follows
[4]:

- Function playing the best elements of corporate culture, the production of new values and their accumulation;

- Function appreciable normative, where comparison based on actual human behavior, groups, corporations with existing cultural norms of behavior and ideals can speak of the positive and negative effects, humane and inhumane, progressive and conservative;

- Function of corporate culture as an indicator and regulator of Conduct;

- The function of learning and mastering corporate culture, carried out at the stage adaptation of the employee contributes to its inclusion in collective activities, determining its future success and career development;

- Transfer function of the corporate values of the value of personal or introduction of the conflict;

- Communicative function, when a value adopted in the organization, rules of conduct and other elements of culture provides employees and their mutual interaction;

- Function preservation and experience of the organization.

There are several points of view on what should be where to start and how should guide the development of corporate culture. The formation of corporate culture must begin with the construction of corporate communications, providing the most complete and accurate reflection of real events occurring in organization.

The main elements of corporate culture, providing an impact on the formation and consolidation of corporate identity, according to experts, are: corporate communications, corporate design, corporate behavior [1].

As noted above, the corporate culture is based on values and organizational norms. Under the rules are understood generalized rules that govern the behavior of employees and lead to the achievement of organizational goals. Roles determine the contribution of each of the joint activity depending occupied it formal or informal positions in the organization, as well as mutual expectations and mutual control staff.Establishment of corporate values - it answers the question:- What we do;- What we fit;- What we are capable of;- That our life guidance;- Which we plan;- Which interest is our business to customers, employees, our partners;- Where my personal position in the overall development plan.Strength of organizational culture is defined by at least two important factors: the degree of acceptance of members of the core values of the company and the degree of their commitment to these values.Difficulties maintain the required level of organizational culture lies in the fact that the newly adopted members bring with them not only new ideas and approaches to solving individual professional goals, and their own values, attitudes, beliefs. Individual employees personal values are formed substantially undermine cultural values within the organization. To maintain the existing system of cultural 
values must always influence the formation of values employees to maximize the convergence of the values of the organization.It is divided socio-psychological meaning of organizational culture on a number of agreed parameters, namely, integration, differentiation and adaptation.Integration. Through the integration of people within the production team may be quite different factors, including: dissatisfaction with management, low wages, social problems, and maybe - total activity only goal, to achieve which staff concentrate all their strength. The integration can be carried out in the following areas:- Identification of methods of communication, the development of procedures for the exchange of views on important issues;- Development of criteria for membership in divisions;- The definition of rules to obtain, and loss of power and status.Differentiation, which can be understood as a clarification of the concept of "uniqueness" to some extent extends the concept of "specialization" within a particular organization.Practice certainly confirms that, ultimately, it is advantageous to invest in its people than long attempt to reappropriate specialist training.Adapting established as a function of corporate culture provides two important parameters of survival in the market. Internal e-mail has long been one of the essential components of the corporate culture of the company. If staff have any questions or there is any problem in this case, he must necessarily submit three possible solutions to this problem:- Specific corporate principles;- Continuous development and improvement;Optimism, striving to give people joy.

\section{Conclusion}

Quality of work can be changed only when a whole begin to treat it with a positive attitude.Systems analysis of employment and remuneration should be comprehensive and mutually agreed. In addition, attention should be focused on those aspects that are closely associated with corporate values. Certainly for companies with strong corporate culture, those who violate the common rules are different kinds of sanctions (from moral condemnation to administrative punishment). These sanctions can be expressed in the latent form, eg transfer the employee to another, less prestigious jobs. Identification of key corporate values helps employees reconcile with the inevitable sacrifices that they offer in order to become members. They gradually begin to accept and then share the values of the organization. At the same time they formed the belief that a company that has such a value system does not do anything to harm them. The organization, in turn, tries to justify these costs by creating your corporate values to higher human values, such as declaring as a public service to improve the quality of their products or services.

\section{References}

[1] Gluxova N. A. Informacionnaya politika universitetov kak osnovnaya sostavlyayushhaya korporativnoj kul'tury' / N. A. Gluxova// Korporativna kul'tura organizacij XXI stolittya : zb. nauk. prac' / za zag. red. S. V. Kovalevs'kogo. - Kramators'k : DDMA, 2007. - S. 161165.

[2] Druker Piter F. E'nciklopediya menedzhmenta : per. s angl. / Piter F. Druker. - M. : Vil'yams, 2004. - 432 s.

[3] Zadixajlo D. V. Korporativne upravlinnya : navchal'nij posibnik / D. V. Zadixajlo, O. R. Kibenko, G. V. Nazarova X. : Espada, 2003. -688 s.

[4] Kovalevskij S. V. Korporativnaya kul'tura kak sreda formirovaniya sistemy' cennostej studenta i vy'pusknika vuza / S. V. Kovalevskij // Korporativna kul'tura organizacij XXI stolittya : zb. nauk. prac' / za zag. red. S. V. Kovalevs'kogo. Kramators'k : DDMA, 2006. - S. 8-11.

[5] Kolodyazhnaya T. P. Obespechenie kachestva pedagogicheskogo processa / T. P. Kolodyazhnaya // Korporativna kul'tura organizacij XXI stolittya : zb. nauk. prac' / za zag. red. S. V. Kovalevs'kogo. - Kramators'k : DDMA, 2010. - S. 113-115.

[6] Korporativna kul'tura : navch. posibnik / G. L. Xaєt, O. L. Es'kov, S. V. Kovalevs'kij [ta in.] ; za zag. red. G. L. Xaєta. K. : Centr navchal'noï literaturi, 2003. - 404 s.

[7] Maslou A. Motivaciya i lichnost' / A. Maslou. - 3-e izd. SPb. : Piter, 2003. - $351 \mathrm{~s}$.

[8] Menedzhment XXI veka : per. s angl. / pod red. S. Choudxari. - M. : INFRA-M, 2002. $448 \mathrm{~s}$.

[9] Meskon M. Osnovy' menedzhmenta : per. s angl. / M. Meskon, M. Al'bert, F. Xedouri. - M. : Delo, 2002. - 704 s.

[10] Pugachev V. P. Rukovodstvo personalom organizacii / V. P. Pugachev. - M. : Aspekt-Press, 1998. - 280 s.

[11] Solomanidina T. O. Organizacionnaya kul'tura kompanii / T. O. Solomanidina. - M. : Infa-M, 2007. - 357 s.

[12] Spivak V. A. Korporativnaya kul'tura / V. A. Spivak. - SPb. : Piter, 2001. $-352 \mathrm{~s}$.

[13] Forsajt R. Fenomen e'kspertny'x sistem / R. Forsajt // E'kspertny'e sistemy' / pod red. R. Forsajta. - M. : Radio i svyaz', 1987. $-36 \mathrm{~s}$.

[14] Yashhishina Yu. M. Spriyannya rozvitku cinnisno-sensovoï sferi students'koï molodi v umovax texnichnogo vishu / Yu. M. Yashhishina // Korporativna kul'tura organizacij XXI stolittya : zb. nauk. prac' / za zag. red. S. V. Kovalevs'kogo. Kramators'k : DDMA, 2010. - S. 121-127. 